AperTO - Archivio Istituzionale Open Access dell'Università di Torino

\title{
Comparative effects of metal oxide nanoparticles on humanairway epithelial cells and macrophages
}

\section{This is the author's manuscript}

Original Citation:

Availability:

This version is available http://hdl.handle.net/2318/1623122

since 2017-07-24T15:56:18Z

Published version:

DOI:10.1007/s11051-012-1069-0

Terms of use:

Open Access

Anyone can freely access the full text of works made available as "Open Access". Works made available under a Creative Commons license can be used according to the terms and conditions of said license. Use of all other works requires consent of the right holder (author or publisher) if not exempted from copyright protection by the applicable law. 


\title{
Comparative effects of metal oxide nanoparticles on human airway epithelial cells and macrophages
}

\author{
Bianca Maria Rotoli • Ovidio Bussolati - Anna Luisa Costa - Magda Blosi • \\ Luisana Di Cristo · Pier Paolo Zanello • Massimiliano G. Bianchi • \\ Rossana Visigalli $\cdot$ Enrico Bergamaschi
}

Received: 22 November 2011/Accepted: 14 July 2012

(C) Springer Science+Business Media B.V. 2012

\begin{abstract}
Among nanomaterials of industrial relevance, metal-based nanoparticles (NPs) are widely used, but their effects on airway cells are relatively poorly characterized. To compare the effects of metal NPs on cells representative of the lung-blood barrier, Calu-3 epithelial cells and Raw264.7 macrophages
\end{abstract}

Special Issue Editors: Candace S.-J. Tsai,

Michael J. Ellenbecker

This article is part of the topical collection on Nanotechnology, Occupational and Environmental Health

Electronic supplementary material The online version of this article (doi:10.1007/s11051-012-1069-0) contains supplementary material, which is available to authorized users.

B. M. Rotoli · O. Bussolati · P. P. Zanello ·

M. G. Bianchi $\cdot$ R. Visigalli

Department of Experimental Medicine, University of Parma, Parma, Italy

A. L. Costa $\cdot$ M. Blosi

Institute of Science and Technology for Ceramics,

National Research Council, Faenza, RA, Italy

L. Di Cristo

Department of Pharmacological, Biological and Applied Chemical Sciences, University of Parma, Parma, Italy

E. Bergamaschi $(\bowtie)$

Unit of Occupational Medicine, Department of Clinical Medicine, Nephrology and Health Sciences, University of Parma, Via Gramsci 14, 43125 Parma, Italy

e-mail: enrico.bergamaschi@unipr.it were incubated with three industrially relevant preparations of $\mathrm{TiO}_{2}$ NPs (size range 4-33 nm), two preparations of $\mathrm{CeO}_{2}$ NPs (9-36 nm) and $\mathrm{CuO}$ NPs $(25 \mathrm{~nm})$. While Raw264.7 were grown on standard plasticware, Calu-3 cells were seeded on permeable filters, where they form a high-resistance monolayer, providing an in vitro model of the airway barrier. Metal NPs, obtained from industrial sources, were characterized under the conditions adopted for the biological tests. Cytotoxicity was assessed with resazurin method in both epithelial and macrophage cells, while epithelial barrier permeability was monitored measuring the trans-epithelial electrical resistance (TEER). In macrophages, titania and ceria had no significant effect on viability in the whole range of nominal doses tested (15-240 $\mu \mathrm{g} / \mathrm{cm}^{2}$ of monolayer), while CuO NPs produced a marked viability loss. Moreover, only $\mathrm{CuO}$ NPs, but not the other NPs, lowered TEER of Calu-3 monolayers, pointing to the impairment of the epithelial barrier. TEER decreased by $30 \%$ at the dose of $10 \mu \mathrm{g} / \mathrm{cm}^{2}$ of CuO NPs, compared to untreated control, and was abolished at doses $\geq 80 \mu \mathrm{g} / \mathrm{cm}^{2}$, in strict correlation with changes in cell viability. These results indicate that (1) $\mathrm{CuO}$ NPs increase airway epithelium permeability even at relatively low doses and are significantly toxic for macrophages and airway epithelial cells, likely through the release of $\mathrm{Cu}$ ions in the medium; (2) $\mathrm{TiO}_{2}$ and $\mathrm{CeO}_{2}$ NPs do not affect TEER and exhibit little acute toxicity for airway epithelial cells and macrophages; and (3) TEER measurement can provide a simple method to assess the impairment 
of in vitro airway epithelial barrier model by manufactured nanomaterials.

Keywords Copper oxide - Titanium oxide · Cerium oxide $\cdot$ Airway epithelium $\cdot$ Nanoparticles

\section{Introduction}

Among engineered nanomaterials, several metaloxide nanoparticles (NPs) are extensively employed in industrial and commercial applications. Titanium dioxide $\left(\mathrm{TiO}_{2}\right)$ NPs occupy the first position in terms of economic importance within the range of metal oxide NPs and are used as pigments in painting industry for their photocatalytic properties (selfcleaning, antibacterial and anti-polluting action) and as sunblocking filter in cosmetics. Due to their antibacterial properties, copper oxide $(\mathrm{CuO})$ NPs are utilized in many products of common use, such as inks, lubricants and coatings. Cerium dioxide $\left(\mathrm{CeO}_{2}\right)$ is currently used as diesel fuel additive, as component in fuel cells and as UV filter in cosmetics.

The exponential increase in metal NPs diffusion requires an in depth knowledge of their toxic properties. Since a variety of physico-chemical parameters of metal NPs, such as size, crystalline structure, chemical composition, surface area, biopersistence, capability to induce oxidative stress, have been considered as main factors for their toxicity, it is very difficult to foresee the toxic effect of newly synthesized NPs. Moreover, it is mandatory to take into account the specific endpoint that may depend on the biological model adopted.

As far as in vitro tests of toxicity are concerned, endpoints may be classified in cell specific and non-cell specific. The endpoints of the second type, such as loss of cell viability, apoptosis induction and genotoxicity, are relevant for almost all the cell models adoptable, although each cell type may have a specific sensitivity to a given nanomaterial (Sayes et al. 2007; Soto et al. 2007; Malugin et al. 2011). On the contrary, alterations in cellspecific functions, possibly of greater toxicological relevance, can be studied only in proper cell types.

Comparative studies may be very useful in characterizing the toxic properties of newly synthesized metal NPs (Lanone et al. 2009; Kroll et al. 2011), avoiding the problematic interpretation of investigations carried on a single NP in a particular cell type and providing relative toxicity indexes. To this purpose, we have undertaken a pilot study on the effects of titanium oxide, cerium oxide and copper oxide NPs on cell-specific and not specific endpoints. We have used Calu-3 epithelial cells and Raw264.7 macrophages, two-cell models representative of, respectively, airway epithelium and macrophages. As for the cell models, Raw 264.7 macrophages are a very commonly used macrophage model in toxicological studies on nanomaterials. Airway macrophages are specialized for interacting with inhaled particles and their exposure to NPs may lead to distinct types of macrophage activation, which account for different pathologic outcomes. On the other hand, Calu- 3 cell line is a representative model of a tight airway epithelium, increasingly used in permeability studies. Airway epithelial cells represent the first anatomical barrier for inhaled NPs, and the contact between the nanomaterials and the epithelium may be prolonged, especially if phagocytosis is impossible or frustrated. Moreover, damage or dysfunction of the epithelial barrier may increase NPs access to lung interstitium and systemic circulation. As non-cell-specific endpoint, we have assessed alterations in cell viability, determined with a standard biochemical method, while, as an example of cell-specific endpoint, we have studied changes in the barrier function of airway epithelial cells.

\section{Materials and methods}

Cells

Calu-3 cells, obtained from a human lung adenocarcinoma and derived from serous cells of proximal bronchial airways (Finkbeiner et al. 1993), were obtained from the Istituto Zooprofilattico Sperimentale della Lombardia ed Emilia-Romagna (Brescia, Italy). Cells were routinely cultured in 10-cm diameter dishes in Eagle's Minimum Essential Medium (EMEM) supplemented with $1 \mathrm{mM}$ sodium pyruvate, $10 \%$ FBS, streptomycin $(100 \mu \mathrm{g} / \mathrm{mL})$ and penicillin $(100 \mathrm{U} / \mathrm{mL})$ in a humidified atmosphere of $5 \% \mathrm{CO}_{2}$ in air. For permeability experiments, Calu- 3 cells were seeded into cell culture inserts with membrane filters (pore size of $0.4 \mu \mathrm{m}$, Cat. No. 3095, Becton, Dickinson \& Company, Franklin Lakes, NJ, USA) for 24-well multitrays, at a density of $75 \times 10^{3}$ cells $/ 250 \mu \mathrm{l}$. Before the permeability experiments, cells were allowed to grow until a value of TransEpithelial 
Table 1 Physicochemical features of target nanomaterials

\begin{tabular}{|c|c|c|c|c|c|}
\hline \multirow[t]{2}{*}{ NPs } & \multirow[t]{2}{*}{ Phase distribution (XRD) } & \multirow[t]{2}{*}{$\mathrm{SSA}\left(\mathrm{BET}, \mathrm{m}^{2} / \mathrm{g}\right)$} & \multicolumn{2}{|c|}{ Water dispersion $^{\mathrm{a}}$} & \multirow[t]{2}{*}{ i.e.p. ${ }^{b}$} \\
\hline & & & $\mathrm{pH}$ & $\mathrm{Z}$ pot $(\mathrm{mV})$ & \\
\hline $\mathrm{TiO}_{2} 1$ & $\begin{array}{l}\text { Anatase } 84 \% \\
\text { Brookite } 16 \%\end{array}$ & 251 & 4.8 & -28.6 & 2.3 \\
\hline $\mathrm{TiO}_{2} 2$ & $\begin{array}{l}\text { Anatase } 83 \% \\
\text { Rutile } 17 \%\end{array}$ & 53 & 3.3 & +59.3 & 4.8 \\
\hline $\mathrm{TiO}_{2} 3$ & $\begin{array}{l}\text { Anatase } 93 \% \\
\text { Rutile } 7 \%\end{array}$ & 93 & 2.3 & +66.1 & 4.1 \\
\hline $\mathrm{CeO}_{2} 1$ & $\mathrm{CeO}_{2}>99.9 \%$ & 40 & 5.2 & -4.9 & 5.0 \\
\hline $\mathrm{CeO}_{2} 2$ & $\mathrm{CeO}_{2}>99.9 \%$ & 12 & 4.9 & -25.5 & 2.6 \\
\hline $\mathrm{CuO}$ & $\begin{array}{l}\mathrm{CuO} 86 \% \\
\mathrm{Cu}_{2} \mathrm{O} 14 \%\end{array}$ & 25 & 4.8 & +73.5 & $9-10^{\mathrm{c}}$ \\
\hline
\end{tabular}

${ }^{a}$ Concentration $1 \mathrm{mg} / \mathrm{mL}, \mathrm{pH}$ for medium dispersion around 7.5

b i.e.p. isoelectric point, $\mathrm{pH}$ value where $\mathrm{Z}$ potential is neutralized $(0 \mathrm{mV})$

c From the literature data (Kittaka and Morimoto 1980)

Electrical Resistance higher than $1,000 \Omega \mathrm{cm}^{2}$ was obtained. For cytotoxicity experiments, whenever not otherwise specified, cells were grown on 24-well plates (Falcon Cat. No. 3047, Becton, Dickinson \& Company).

Raw264.7 macrophages were obtained from the Istituto Zooprofilattico Sperimentale della Lombardia ed Emilia-Romagna and routinely cultured in 10-cm diameter dishes in RPMI1640 medium supplemented with $10 \%$ FBS and antibiotics. For the experiments, cells were seeded on 96-well microplates (Falcon Cat. No. 3072).

\section{Characterization of nanoparticles}

The panel of metal oxide NPs used consisted of: (a) three preparations of $\mathrm{TiO}_{2}$ NPs synthesized for industrial applications [from Colorobbia, Montelupo Fiorentino FI Italy $\left(\mathrm{TiO}_{2} 1\right)$, Evonik Degussa GmbHAeroxide P25 $\left(\mathrm{TiO}_{2} 2\right)$, and Thetis SpA, Milan, Italy $\left.\left(\mathrm{TiO}_{2} 3\right)\right]$; (b) two preparations of $\mathrm{CeO}_{2} \mathrm{NPs}\left(\mathrm{CeO}_{2} 1\right.$ and 2, both from Nanostructured \& Amorphous Materials Inc., Houston, Texas, USA), and (c) $\mathrm{CuO}$ NPs (from Intrinsiq Materials Inc., Rochester, NY, USA). $\mathrm{TiO}_{2} 2$ and 3 were used as received from the manufacturers, while $\mathrm{TiO}_{2} 1$, purchased as stable nanosol, was dried by spray-drying in order to be processed for toxicological tests. The main characteristics of the NPs used are summarized in Table 1, while the methods adopted for their characterization are detailed below.
Particle size distribution, based on hydrodynamic diameter, was evaluated by dynamic light scattering (DLS) technique. A nanometric particle size analyzer, Zetasizer Nano S (Malvern Instruments, Malvern, Worcestershire, UK) was used; scattering data were recorded at $25 \pm 1{ }^{\circ} \mathrm{C}$ in backscattering modus at a scattering angle of $2 \mathrm{~h}=173^{\circ}$. Each result corresponds to the average of five measurements, and each measurement is averaged within 15 performed analyses. Hydrodynamic diameter includes the coordination sphere and the species adsorbed on the particle surface such as stabilizers, surfactants, and so forth. DLS analysis provides also a polydispersion index (PDI), ranging from 0 to 1 , to quantify the colloidal dispersion degree; for PDI lower than 0.3 samples may be considered monodispersed. Stock solutions $(1 \mathrm{mg} / \mathrm{mL})$ were ultrasonicated for $15 \mathrm{~min}$ and diluted to $0.1 \mathrm{mg} / \mathrm{mL}$, both in water and RPMI1640 medium. DLS analyses were performed on both the diluted solutions.

The Zeta potential of stock solutions was measured by an electroacoustic technique (AcoustoSizer II Colloidal Dynamics, Sydney, Australia) based on the measure of the Electrokinetic Sonic Amplitude (ESA) signal generated in the colloidal systems. The ESA signal is an electrokinetic effect, generated by the motion of charged particles dispersed in a liquid when an alternate electric field is applied, that is related to the Zeta potential according to the theory developed by O'Brien et al. (1995). Moreover the system is equipped with an automatic $\mathrm{pH}$ titrating system used to 
determine the Zeta potential of nanosols as a function of $\mathrm{pH}$ and to detect the isoelectric point (i.e.p), corresponding to a Zeta value of $0 \mathrm{mV}$. The analyses were performed on stock solutions $(1 \mathrm{mg} / \mathrm{mL})$.

The specific surface area (SSA) was determined by BET single point method (Brunauer et al. 1938) with a Sorpty 1750 apparatus (Carlo Erba, Milano, Italy). For spherical shape powder particles, it is possible to calculate one of the following parameters linked by a simple geometric relationship (German and Park 2008):

$\mathrm{SSA}=\frac{\text { Area }_{\mathrm{tot}}}{\mathrm{M}_{\mathrm{tot}}}=\frac{\mathrm{n} \cdot \pi \cdot \phi^{2}}{\mathrm{n} \cdot 1 / 6 \cdot \pi \cdot \phi^{3} \cdot \rho}=\frac{6}{\phi \cdot \rho}$

where, SSA is the specific surface area $\left(\mathrm{m}^{2} / \mathrm{g}\right), \phi$ is the particle mean diameter $(\mu \mathrm{m})$, and $\rho$ is the powder density $\left(\mathrm{g} / \mathrm{cm}^{3}\right)$

Applying this relationship, it was possible to calculate the particle mean diameter from SSA, to compare it with hydrodynamic diameter (DLS), aggregate size (SEM) and crystallite size (XRD) and to make some hypothesis on the morphology of primary particles and aggregates.

The XRD analysis allowed an estimation of amount of different phases present into the powder samples. Analyses were performed by a D500 diffractometer (Siemens, Munich, Germany), operating with Nifiltered $\mathrm{Cu}$ Ka radiation (35-52 29 range, $0.02 \mathrm{~s}^{-1}$, 3 s time-per-step). A Reference Intensity Ratio (RIR) was applied, basing upon scaling all diffraction data to the diffraction of standard reference materials (scale factor defined by: Intensity Analyte/Intensity Corundum $=I / I c)$.

Nickel nanoparticles (Byrne et al. 2009; Poland et al. 2011) were used as positive controls in cytotoxicity experiments.

\section{Experimental treatments}

Before the experiments, metal NPs were heated at $220{ }^{\circ} \mathrm{C}$ for $3 \mathrm{~h}$ to eliminate possible contamination from lipopolysaccharide. After cooling at room temperature, nanomaterials were dispersed at a concentration of $2 \mathrm{mg} / \mathrm{mL}$ in sterile phosphate-buffered saline (PBS). Immediately before experiments, the stock suspensions were extensively vortexed and sonicated for $15 \mathrm{~min}$ in a Bransonic Ultrasonic ultrasound bath. Stocks were used for no more than five experiments and maintained frozen in the intervals among the experiments. NPs were added to normal growth medium to reach the desired dose. Taking into account the volume/surface ratio of the various culture systems adopted and the use of subconfluent (cytotoxicity) or confluent monolayers (permeability studies), we have expressed the nominal doses as $\mu \mathrm{g}$ of materials per $\mathrm{cm}^{2}$ of monolayer.

\section{Viability}

Cell viability was assessed by the resazurin method (O'Brien et al. 2000). According to this method, viable cells reduce the non-fluorescent compound resazurin into the fluorescent resorufin that accumulates into the medium. After the exposure to NPs, carried on in thermostat, cells were incubated for $1 \mathrm{~h}$ with fresh, serum-free medium supplemented with $44 \mu \mathrm{M}$ resazurin; fluorescence was then measured at $572 \mathrm{~nm}$ with a fluorimeter (Wallac 1420 Victor2 Multilabel Counter, Perkin Elmer, Waltham, MA, USA).

For Calu-3 monolayers grown in a double chamber culture system, resazurin was added at both sides of the monolayer and fluorescence was measured in the apical compartment (Rotoli et al. 2009). Since NPs may interfere with the adopted viability method, the possible interference of the metal NPs with resorufin fluorescence has been excluded in preliminary experiments, according to the protocol previously adopted for MultiWalled Carbon Nanotubes (Rotoli et al. 2008).

Viability was also assessed through the direct observation of treated cultures by light microscopy, evaluating cell density and the presence of morphological alterations, such as cell rounding. Images of cells in phase contrast were obtained with a Nikon DS5MC digital camera (Nikon Instruments SpA, Firenze, Italy).

\section{ROS generation}

ROS generation was measured by a fluorometric assay using 5-(and-6)-chloromethyl-2', 7'-dichlorodihydrofluorescein diacetate, acetyl ester $\left(\mathrm{CM}-\mathrm{H}_{2} \mathrm{DCF}-\mathrm{DA}\right.$, Cat. No. C6827, Molecular Probes, Invitrogen, Grand Island, NY, USA). After the experimental treatments, cells were incubated with the probe $(5 \mu \mathrm{M})$ for $40 \mathrm{~min}$. Cells were then washed and the fluorescence in cells was visualized using a fluorescence microscope (Nikon, Tokyo, Japan). Cells were then scraped, lysed in RIPA buffer (RadioImmunoPrecipitation Assay buffer, a buffer commonly used to lyse mammalian 
Table 2 Comparison between particle size assessed by different techniques

\begin{tabular}{|c|c|c|c|c|c|c|}
\hline & \multicolumn{2}{|c|}{ Mean hydrodynamic diameter (DLS, nm/PDI) ${ }^{\mathrm{a}}$} & \multicolumn{2}{|c|}{ Phase, crystallite size (nm) } & \multirow{2}{*}{$\begin{array}{l}\text { Equivalent } \\
\text { spherical } \\
\text { diameter } \\
(\mathrm{BET}, \mathrm{nm})\end{array}$} & \multirow{2}{*}{$\begin{array}{l}\text { Aggregate } \\
\text { size }(\mathrm{SEM}, \mu \mathrm{m})\end{array}$} \\
\hline & Water & Medium & & & & \\
\hline $\mathrm{TiO}_{2} 1$ & $266 / 0.6$ & $609 / 0.8$ & Anat., 4 & Brook., 4 & 6 & $\approx 5$ \\
\hline $\mathrm{TiO}_{2} 2$ & $360 / 0.3$ & $1,090 / 0.7$ & Anat., 22 & Rutile, 33 & 30 & $\approx 3$ \\
\hline $\mathrm{TiO}_{2} 3$ & $2,135 / 0.4$ & $1,770 / 0.4$ & Anat., 16 & Rutile, 20 & 17 & $\approx 20$ \\
\hline $\mathrm{CeO}_{2} 1$ & $1,280 / 0.9$ & $1,685 / 0.9$ & $\mathrm{CeO}_{2}, 9$ & & 20 & - \\
\hline $\mathrm{CeO}_{2} 2$ & $133 / 0.8$ & $746 / 0.9$ & $\mathrm{CeO}_{2}, 36$ & & 65 & - \\
\hline $\mathrm{CuO}$ & $283 / 0.3$ & $1,200 / 0.6$ & $\mathrm{CuO}, 25$ & & 24 & - \\
\hline
\end{tabular}

PDI polydispersity index. PDI $<0.3$ monodispersed suspension, PDI $>0.3$ polydispersed suspension

${ }^{\text {a }}$ Concentration $0.1 \mathrm{mg} / \mathrm{mL}$
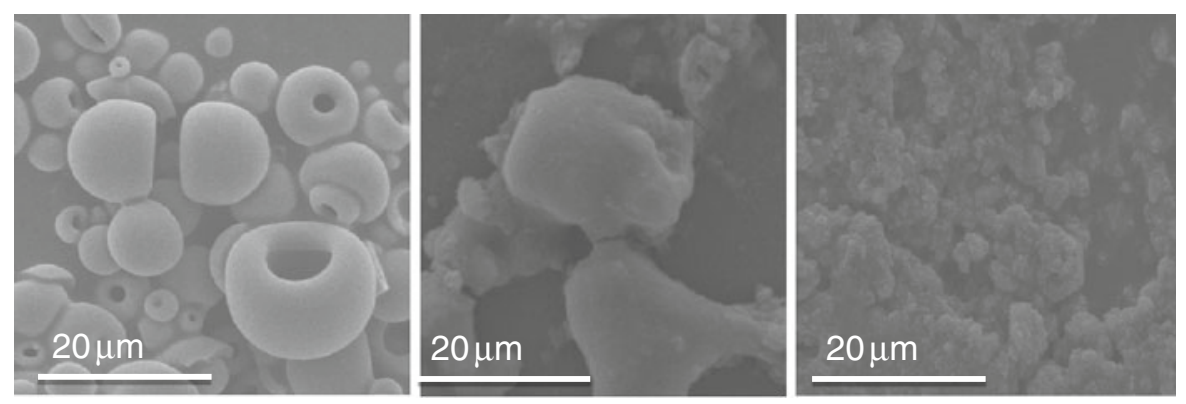

Fig. 1 SEM micrographs of $\mathrm{TiO}_{2} 1$ (left), $\mathrm{TiO}_{2} 2$ (middle) and $\mathrm{TiO}_{2} 3$ (right) samples

cells: 20 mM Tris-HCl(pH 7.5); $150 \mathrm{mM} \mathrm{NaCl}, 1 \mathrm{mM}$ $\mathrm{Na}_{2}$ EDTA; 1 mM EGTA; $1 \%$ NP-40; $1 \%$ sodium deoxycholate; $2.5 \mathrm{mM}$ sodium pyrophosphate; $1 \mathrm{mM}$ $\beta$-glycerophosphate; $1 \mathrm{mM} \mathrm{Na} \mathrm{VO}_{4} ; 1 \mu \mathrm{g} / \mathrm{mL}$ leupeptin), pulse sonicated for $15 \mathrm{~s}$ and centrifuged at $12,000 \times g$ for $15 \mathrm{~min}$ at $4{ }^{\circ} \mathrm{C}$, and fluorescence was measured with a Wallac Victor 2 microplate reader. Before centrifugation, an aliquot of lysate was used to determine protein content with the method of Bradford. The intensity of fluorescence was expressed as Arbitrary Units (AU) per $\mu \mathrm{g}$ of protein.

To estimate ROS generation in acellular systems, the probe $(5 \mu \mathrm{M})$ was added to growth medium supplemented with the NPs, and fluorescence was read with a Wallac Victor 2 microplate reader after $60 \mathrm{~min}$ of incubation.

Trans-epithelial electrical resistance (TEER)

For measurements of TransEpithelial Electrical Resistance (TEER) Calu-3 cells were seeded into cell culture inserts with membrane filters (pore size of $0.4 \mu \mathrm{m}$ ) for
Falcon 24-well-multitrays (Cat. No. 3095, Becton, Dickinson \& Company, Franklin Lakes, NJ, USA), at a density of $75 \times 10^{3}$ cells $/ 250 \mu \mathrm{l}$. Before the permeability experiments, cells were allowed to grow, usually for 10-14 days, until a value of TEER higher than $1,000 \Omega \mathrm{cm}^{2}$ was reached, indicating the formation of a tight epithelial layer. TEER measurements were made using an epithelial voltohmeter (EVOM, World Precision Instruments Inc., Sarasota, FL, USA). Materials were added in the apical chamber from the stock solutions without changing the medium. TEER changes were expressed as the percentage of the initial value adjusted for control cell layers according to the equation (Salem et al. 2009).

$$
\begin{aligned}
& \text { TEER } \%=\frac{\text { Final } \text { TEER }_{\text {treated }}}{\text { Final } \text { TEER }_{\text {control }}} \times \frac{\text { Initial TEER }}{\text { control }} \\
& \times 100
\end{aligned}
$$

\section{Statistics}

Values of viability and TEER were analysed with ANOVA using post hoc Bonferroni test. 

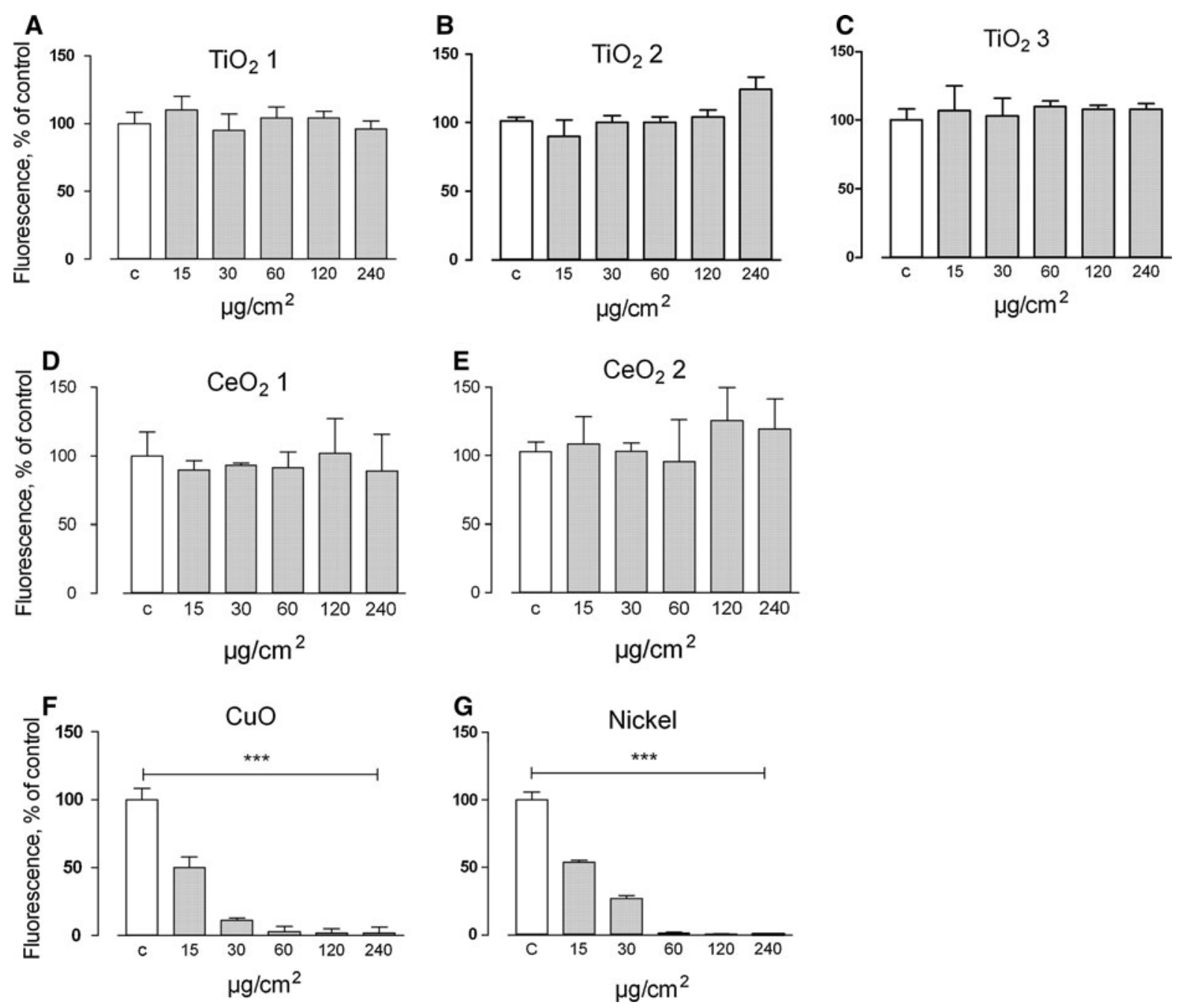

Fig. 2 Effects of metal oxide NPs on macrophage viability. Raw264.7, grown for $48 \mathrm{~h}$ in complete growth medium, were treated for $24 \mathrm{~h}$ with the indicated NPs. At the end of the incubation, cell viability was assessed with the resazurin method

\section{Reagents}

FBS and culture media were purchased from EuroClone SpA, Pero, Milan, Italy. Sigma-Aldrich (Milan, Italy) was the source of all other chemicals, whenever not specified otherwise.

\section{Results}

Physico-chemical characterization of NPs

The main characteristics of the NPs investigated are reported in Table 1, while information about particle (see 'Materials and methods' section). Data are means of five independent determinations with SD shown. The experiment was repeated twice with comparable results. $* * * P<0.01$ versus untreated, control cells

size is summarized in Table 2. All particles have a micrometric aggregate structure, evidenced by hydrodynamic diameter-measured by DLS-and morphology - detected by SEM-similar to that shown in Fig. 1 for $\mathrm{TiO}_{2}$ powders, and resulted polydispersed, with the exception of $\mathrm{TiO}_{2} 2$ and $\mathrm{CuO}$ in water. Nevertheless, the aggregates have a primary nanostructure, as assessed by crystallite size and BET equivalent spherical diameter. These two techniques yielded comparable values, indicating the presence of discrete nanometric units with crystalline order that form the aggregate structure. The primary particle size of investigated powders is about $20.0-30.0 \mathrm{~nm}$, with 

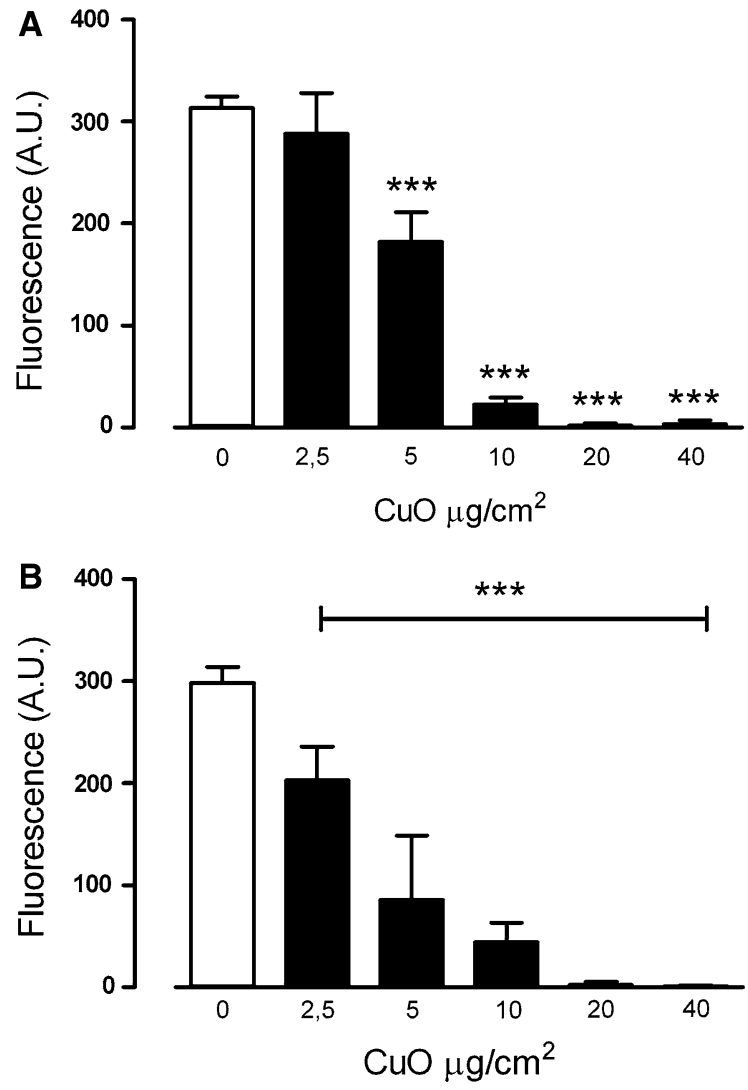

Fig. 3 Effects of $\mathrm{CuO}$ NPs on macrophage viability. Raw264.7, grown for $48 \mathrm{~h}$ in complete growth medium, were treated for $24 \mathrm{~h}(\mathbf{a})$ or $48 \mathrm{~h} \mathrm{(b)} \mathrm{with} \mathrm{the} \mathrm{indicated} \mathrm{doses} \mathrm{of} \mathrm{CuO}$ NPs. At the end of the incubation, cell viability was assessed with the resazurin method (see 'Materials and methods' section). Data are means of five independent determinations with SD shown. The experiment was repeated three times with comparable results. $* * * P<0.01$ versus untreated, control cells

exception for $\mathrm{TiO}_{2} 1$ that shows the finest nanostructure (BET diameter of $6 \mathrm{~nm}$ ) and $\mathrm{CeO}_{2} 2$ that shows the largest nanostructure (BET diameter of $65 \mathrm{~nm}$ ).

An increase of the mean hydrodynamic diameters, associated to a lower colloidal stability, was observed for all the samples dispersed in RPMI1640 medium. Agglomeration phenomena detected passing from the water solution to the medium can be attributed to the higher ionic strength of the medium and to the presence of divalent $\left(\mathrm{Ca}^{2+}\right.$ and $\left.\mathrm{Mg}^{2+}\right)$ cations that shift the isoelectric point towards the more basic medium pH (Long et al. 2006).

$\mathrm{CeO}_{2}$ suspensions showed the lowest degree of stability; in particular $\mathrm{CeO}_{2} 1$ suspension was completely precipitated after $1 \mathrm{~h}$-settling (Supplementary
Fig. 1), in spite of the lower BET equivalent diameter than $\mathrm{CeO}_{2}$ 2. The higher stability of $\mathrm{CeO}_{2} 2$ is justified by the more negative Zeta potential $(-4.9 \mathrm{mV}$ for $\mathrm{CeO}_{2} 1,-25.5 \mathrm{mV}$ for $\mathrm{CeO}_{2}$ 2), due to the shift of isoelectric point from 5.0, for sample $\mathrm{CeO}_{2} 1$ [in agreement with (Mao et al. 2010)] to 2.6 for $\mathrm{CeO}_{2} 2$, far from its natural $\mathrm{pH}$ (4.9 vs. 5.2 for $\mathrm{CeO}_{2} 1$ ).

The detected difference between the isoelectric points of two different $\mathrm{CeO}_{2}$ samples agrees with a trend observed in the literature for $\mathrm{TiO}_{2}$ nano powders prepared with the same synthetic procedure but having different BET equivalent diameters, where a shift of isoelectric point towards more acidic region was detected at increasing primary particle sizes (Suttiponparnit et al. 2011).

For titania, the electroacoustic technique applied here has yielded, for $\mathrm{TiO}_{2} 2$ in water, an acid $\mathrm{pH}$, probably due to residual synthesis byproducts and an i.e.p. of 4.8, with a Zeta potential at natural $\mathrm{pH}$ quite high $(+59.3)$. A quite similar behaviour was detected for $\mathrm{TiO}_{2} 3$ sample, while $\mathrm{TiO}_{2} 1$ sample resulted negatively charged $(-28.6 \mathrm{mV})$ at natural $\mathrm{pH}(4.8)$ with an isoelectric point of 2.3 justifiable by anionic species adsorbed into $\mathrm{TiO}_{2}$ surface added during solgel synthesis. Nevertheless, the large aggregates $(\approx 20 \mu \mathrm{m})$ of $\mathrm{TiO}_{2} 3$ sample, evidenced by SEM measurements justifies the higher sedimentation rate and the larger hydrodynamic diameters detected by DLS measurements.

The $\mathrm{CuO}$ natural $\mathrm{pH}$ of 4.8 (in water) is far enough from its isoelectric point, which ranges from 9 to 10 (Kittaka and Morimoto 1980), so as to ensure a relatively good colloidal stability.

Effects of metal NPs on the viability of Raw264.7 cells

Figure 2 (panels a-e) depicts the effects of $\mathrm{TiO}_{2}$ and $\mathrm{CeO}_{2}$ NPs on the viability of Raw264.7 cells in a dose range between 15.0 and $240.0 \mu \mathrm{g} / \mathrm{cm}^{2}$ of monolayer (corresponding to 22.5 and $360 \mu \mathrm{g} / \mathrm{mL}$ in the culture system adopted). No significant loss of viability was recorded with any NP. On the contrary, CuO NPs (Fig. 2f) had very marked effects on cell viability, comparable to that observed upon treatment with $\mathrm{Ni}$ NPs, used as a positive control (Panel g).

A similar experiment, performed in a lower range of doses of $\mathrm{CuO}$ NPs (Fig. 3), indicated significant toxicity at doses $\geq 5.0 \mu \mathrm{g} / \mathrm{cm}^{2}$ after $24 \mathrm{~h}$ of exposure 

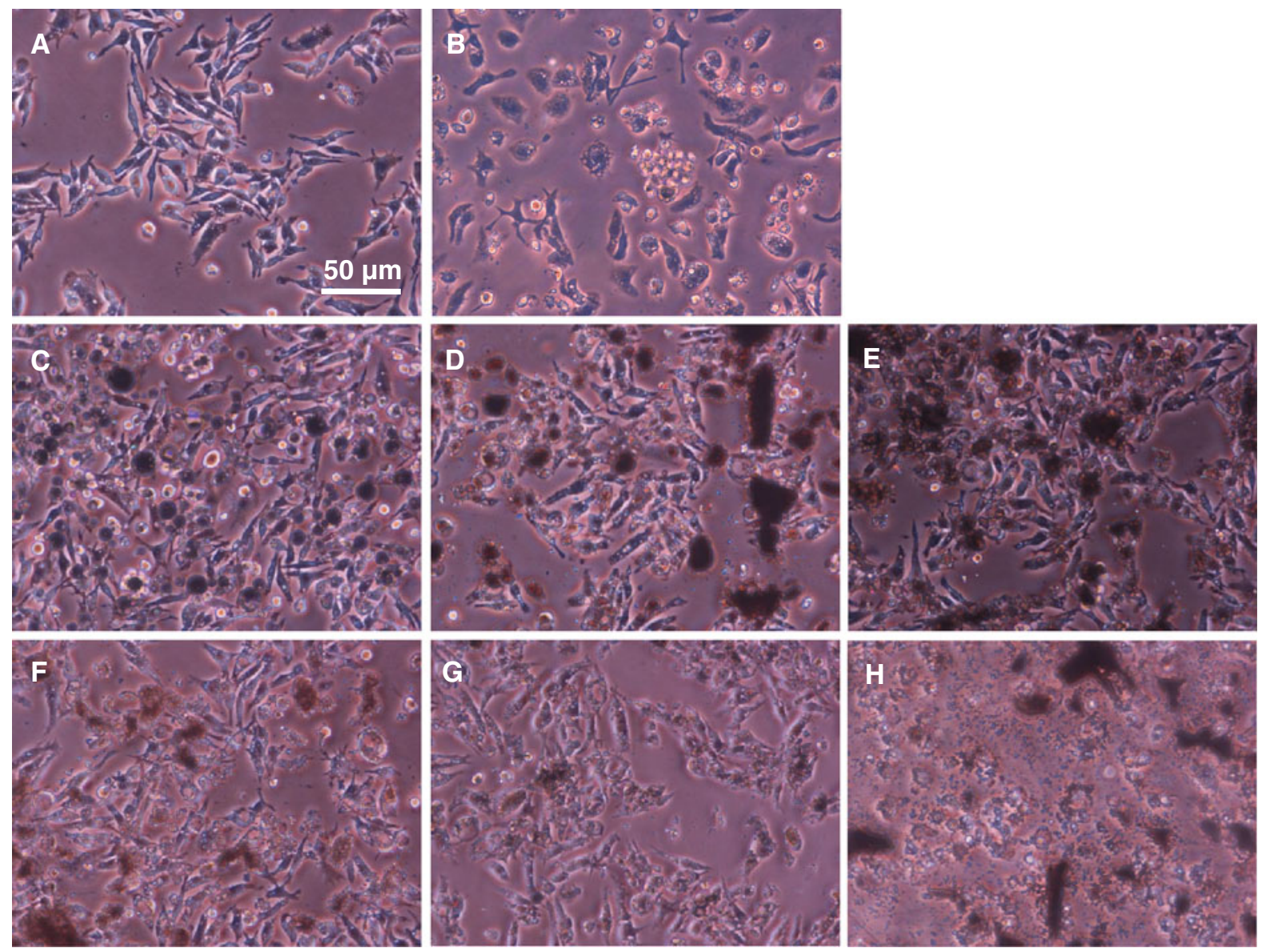

Fig. 4 Effects of metal oxide NPs on macrophage viability. Raw264.7 cells were incubated for $24 \mathrm{~h}$ in growth medium in the absence (a control) or in the presence of the following NPs: Nickel $\left(30 \mu \mathrm{g} / \mathrm{cm}^{2}, \mathbf{b}\right.$ positive control), $\mathrm{TiO}_{2} 1\left(80 \mu \mathrm{g} / \mathrm{cm}^{2} \mathbf{c}\right)$, $\mathrm{TiO}_{2} 2\left(80 \mu \mathrm{g} / \mathrm{cm}^{2} \mathbf{d}\right), \mathrm{TiO}_{2} 3\left(80 \mu \mathrm{g} / \mathrm{cm}^{2} \mathbf{e}\right), \mathrm{CeO}_{2} 1\left(80 \mu \mathrm{g} / \mathrm{cm}^{2}\right.$

while, at $48 \mathrm{~h}$, even the lowest dose employed $\left(2.5 \mu \mathrm{g} / \mathrm{cm}^{2}\right)$ caused a significant viability loss; macrophage viability was substantially suppressed after $24 \mathrm{~h}$ of exposure at doses $>10.0 \mu \mathrm{g} / \mathrm{cm}^{2}$ (corresponding to $15 \mu \mathrm{g} / \mathrm{mL}$ ).

Microscopic observation was used to confirm the results of the biochemical test. Compared to untreated cultures (Fig. 4a), the positive control, consisting of $\mathrm{Ni}$ NPs, produced evident cell loss and rounding. On the contrary, $\mathrm{TiO}_{2}$ and $\mathrm{CeO}_{2}$ NPs did not markedly affect culture morphology, even if NP aggregates were clearly detectable on the monolayer surface (Fig. 4 c-g). Conversely, CuO NPs, at a dose of $20.0 \mu \mathrm{g} / \mathrm{cm}^{2}$, produced an evident cell loss (Fig. 4h). f), $\mathrm{CeO}_{2} 2\left(80 \mu \mathrm{g} / \mathrm{cm}^{2} \mathbf{g}\right)$ and $\mathrm{CuO}\left(20 \mu \mathrm{g} / \mathrm{cm}^{2} \mathbf{h}\right)$. At the end of the incubation, cultures were observed in phase contrast. Images of representative field are shown. The experiment was repeated two times with comparable results

The effects of $\mathrm{CuO}$ NPs were compared with those of $\mathrm{Cu}^{++}$ions (supplemented to the growth medium as $\mathrm{CuCl}_{2}$ ) at equivalent doses of copper (Fig. 5). The results indicated that, at comparable Copper content in the assays, $\mathrm{CuO} \mathrm{NPs}$ and $\mathrm{CuCl}_{2}$ gave similar effects.

The induction of oxidative stress by the panel of selected NPs was then investigated in the experiments shown in Figs. 6 and 7. In the experiment shown in Fig. 6, the effect of the six NPs on the production of ROS, evaluated from the changes in carboxyfluorescein fluorescence, was assessed in the absence of cells, demonstrating that only $\mathrm{CuO}$ NPs produced a significant increase of fluorescence. Supplementation with the antioxidant $\mathrm{N}$-acetyl-cysteine (NAC) significantly 

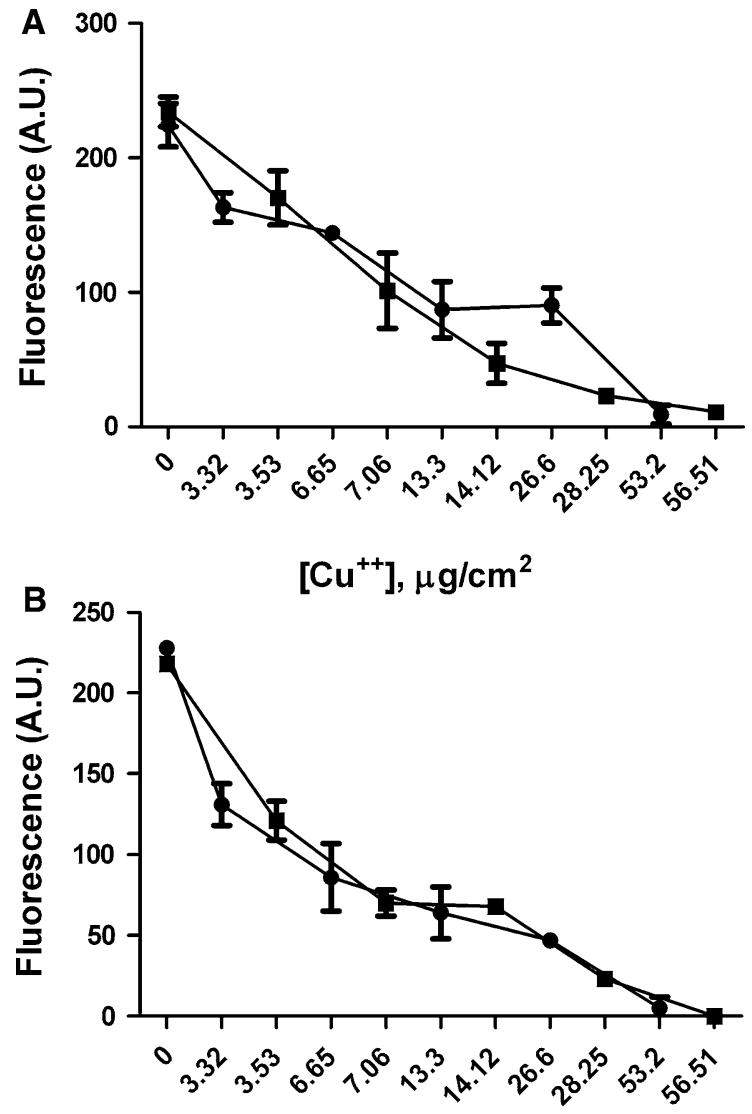

$\left[\mathrm{Cu}^{++}\right], \mu \mathrm{g} / \mathrm{cm}^{2}$

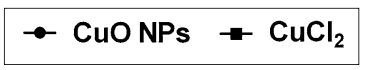

Fig. 5 Comparison between the effects of $\mathrm{CuCl}_{2}$ and $\mathrm{CuO}$ NPs on macrophage viability. Raw264.7 cells were incubated for $24 \mathrm{~h}$ (a) or $48 \mathrm{~h}$ (b) with increasing doses of $\mathrm{CuCl}_{2}$ and $\mathrm{CuO}$ NPs, selected to cover a comparable range of copper concentrations (from 0 to $53.2 \mu \mathrm{g} / \mathrm{cm}^{2}$ of copper for $\mathrm{CuO} \mathrm{NP}$, from 0 to $56.51 \mu \mathrm{g} / \mathrm{cm}^{2}$ of copper for $\mathrm{CuCl}_{2}$ ). At the end of the incubation, cell viability was determined with the resazurin method. Data are means of five independent determinations with SD. The experiment was performed twice with comparable results

reduced the fluorescence increase due to $\mathrm{CuO}$ NPs. When $\mathrm{CuO}$ NPs were added to the growth medium of Raw264.7 cells, a clear cut intracellular ROS production was evident from the increase in fluorescence detected in both cell lysates (Fig. 7a) and cells in situ (Fig. 7b). Consistently with a role of ROS in $\mathrm{CuO}$ NPs effects, the addition of NAC significantly protected Raw264.7 cells from the cytotoxicity induced by sub-maximal doses of this nanomaterial (Fig. 8).

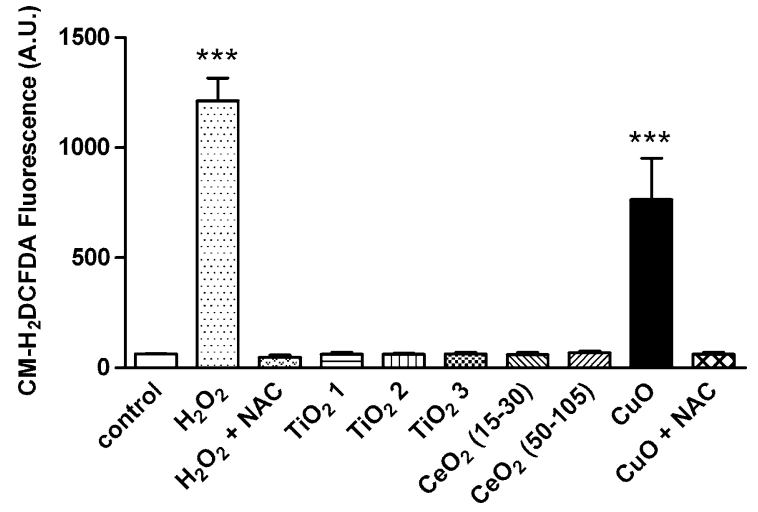

Fig. 6 ROS production by metal oxide NPs in acellular systems. $100 \mu \mathrm{l}$ of medium were supplemented with CM$\mathrm{H}_{2}$ DCF-DA $(5 \mu \mathrm{M})$ and $20 \mu \mathrm{g} / \mathrm{cm}^{2}$ of the indicated NP for $60 \mathrm{~min} . \mathrm{H}_{2} \mathrm{O}_{2}(2 \mathrm{mM})$ was added as a positive control. NAC Nacetyl-cysteine $2 \mathrm{mM}$. Fluorescence was determined after $60 \mathrm{~min}$ as described under 'Materials and methods' section. Data are means of four independent determinations with SD. The experiment was repeated three times with comparable results. $* * * P<0.01$ versus untreated, control cells

Effects of metal NPs on the transepithelial electrical resistance in Calu-3 cell monolayers

After reaching confluence on membrane filters, Calu-3 monolayers develop progressively high transepithelial electrical resistance (TEER), forming a competent epithelial barrier. The addition of $\mathrm{CuO}$ NPs to the apical compartment of these monolayers had impressive effects on TEER. In the experiment shown in Fig. 9, CuO NPs were added to high-TEER, confluent monolayers. Control monolayers, not treated with the NPs, further increased TEER above the initial value. $\mathrm{CuO}$ NPs lowered TEER in a dose-dependent way. Indeed, after 2 days of exposure to $10.0 \mu \mathrm{g} / \mathrm{cm}^{2}$ of $\mathrm{CuO}$ NPs, TEER of treated monolayers was already significantly lower than untreated counterpart (30\%) and at doses $\geq 80.0 \mu \mathrm{g} / \mathrm{cm}^{2}$ TEER was abolished. Conversely, the other metal NPs had no apparent effect on TEER, given that, even when used at high doses $\left(120 \mu \mathrm{g} / \mathrm{cm}^{2}\right)$, neither $\mathrm{TiO}_{2}$ nor $\mathrm{CeO}_{2} \mathrm{NPs}$ affected the resistance, even if the TEER of parallel monolayers was clearly affected by $40 \mu \mathrm{g} / \mathrm{cm}^{2}$ of $\mathrm{CuO}$ NPs (Fig. 10). The relationship between cytotoxicity and epithelial barrier impairment was investigated studying in the same monolayers the effects on TEER and cell viability of low doses of CuO NPs (Fig. 11). The results indicate that there was a close association between viability lowering and TEER decrease. 

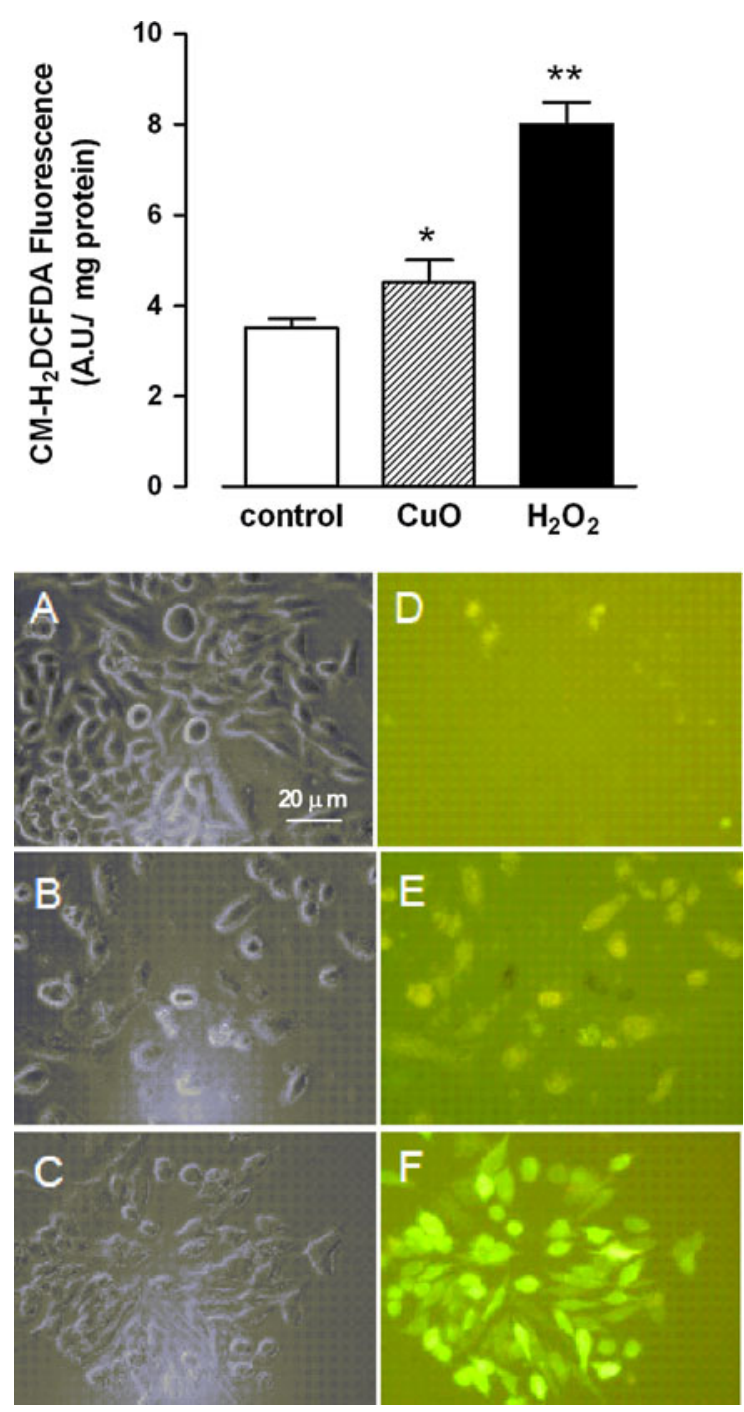

Fig. 7 ROS production by metal oxide NPs in Raw264.7 cells. Upper Raw264.7 cells were incubated for $24 \mathrm{~h}$ in the absence (control) or in the presence of $\mathrm{CuO}$ NPs $\left(5 \mu \mathrm{g} / \mathrm{cm}^{2}\right)$ or $\mathrm{H}_{2} \mathrm{O}_{2}$ $(2 \mathrm{mM})$. At the end of the incubation, cells were incubated for 30 min with CM- $\mathrm{H}_{2}$ DCF-DA $(5 \mu \mathrm{M})$. Fluorescence was determined as described in 'Materials and methods' section. Data are means of three independent determinations with SD. The experiment was performed three times with comparable results. $* P<0.05$, ** $P<0.01$. Lower before determination of the intracellular CM- $\mathrm{H}_{2} \mathrm{DCF}-\mathrm{DA}$, images of representative fields were taken in phase contrast $(\mathbf{a}-\mathbf{c})$ or with fluorescence microscope (d-f). a, d control, untreated cultures. b, e $\mathrm{CuO}$ NPs. c, f $\mathrm{H}_{2} \mathrm{O}_{2}$

\section{Discussion}

The main findings gathered by our study are the following: (i) $\mathrm{CuO}$ NPs exert dose dependent toxicity

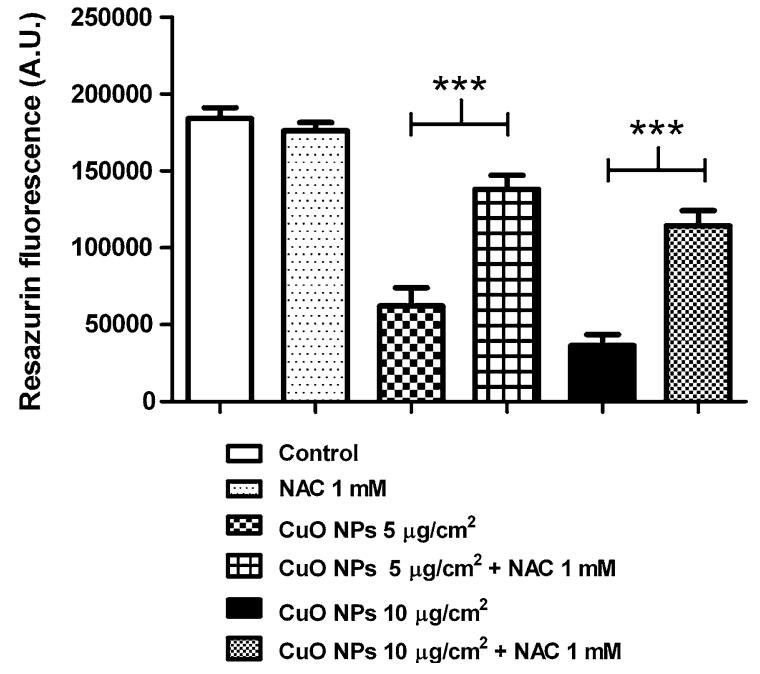

Fig. 8 Protection of Raw264.7 from CuO NPs by antioxidants. Raw264.7 cells were incubated for $24 \mathrm{~h}$ with $\mathrm{CuO}$ NPs ( 5 or $\left.10 \mu \mathrm{g} / \mathrm{cm}^{2}\right)$ in the presence or in the absence of NAC $(1 \mathrm{mM})$. At the end of the incubation, cell viability was assessed with the resazurin method. Control, cells treated with neither $\mathrm{CuO}$ NPs nor NAC. Data are means of five independent determinations with SD. The experiment was repeated three times with comparable results. $* * * P<0.01$ versus cells treated with the same dose of $\mathrm{CuO}$ NPs in the absence of NAC

on both macrophages and airway epithelial cells with comparable potency; (ii) in airway epithelial cell monolayers, the exposure to $\mathrm{CuO}$ NPs causes a dosedependent, progressive TEER decrease, pointing to the impairment of the epithelial barrier; (iii) as a toxicity indicator, TEER is as sensitive as changes in cell viability, determined with biochemical methods. Actually, the results shown indicate a strict correlation between TEER decrease and viability loss; (iv) $\mathrm{TiO}_{2}$ and $\mathrm{CeO}_{2}$ NPs are not significantly toxic on macrophages and do not cause marked TEER changes in epithelial cell monolayers.

Copper oxide NPs have been consistently reported as being endowed with significant cytotoxicity (Karlsson et al. 2008; Lanone et al. 2009; Studer et al. 2010), and the results shown here clearly suggest that epithelial barrier perturbation must be included among the toxic effects of this nanomaterial. CuO NP cytotoxicity seems correlated to oxidative stress, since cell production of ROS is already evident at the lowest cytotoxic dose, and NAC exerts a significant protective role. The higher toxicity shown by $\mathrm{CuO}$ NPs in comparison with $\mathrm{TiO}_{2}$ and $\mathrm{CeO}_{2}$ powders can be related to the stability of $\mathrm{CuO}$ NPs dispersions, that are 


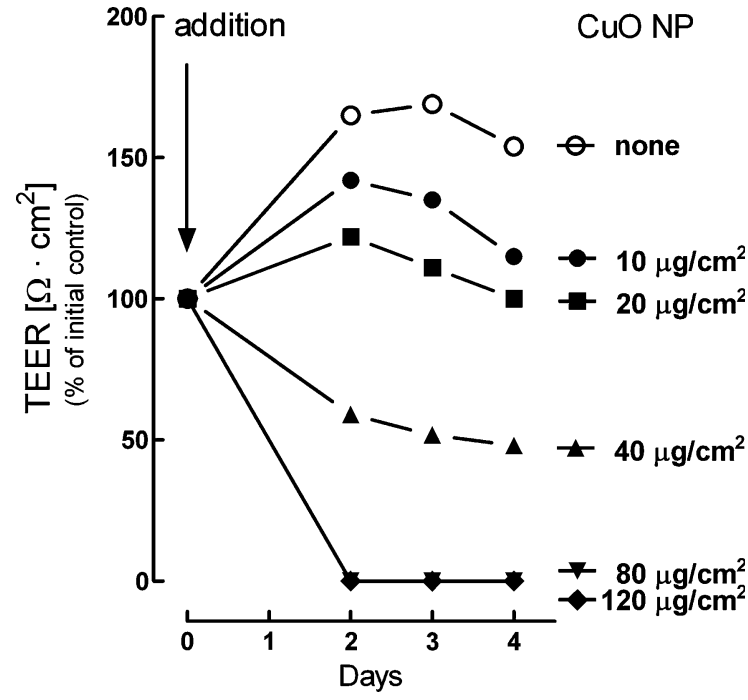

Fig. 9 Effects of $\mathrm{CuO}$ NPs on the trans-epithelial electrical resistance (TEER) of Calu-3 cell monolayers. Confluent Calu-3 monolayers, grown for 13 days, were incubated in the presence of the indicated doses of CuO NPs, added at the apical side of the monolayer (Time 0). The trans-epithelial electrical resistance (TEER) was measured (see 'Materials and methods' section) on daily basis from the second to the fourth day of treatment. Data are values obtained from single monolayers and are expressed as $\%$ of the initial value (see 'Materials and methods' section). The experiment was repeated four times with comparable results

remarkably more stable compared to titania and ceria dispersions, and to their positive $\mathrm{Z}$ potential. Positive $\mathrm{Z}$ potential can affect toxicity mechanism, given that it is documented that cationic surfaces generally exert stronger effects than their anionic counterparts (Nel et al. 2009). However, at variance with what reported by others in A549 cells (Karlsson et al. 2008), a strict parallelism exists between the toxic effects caused by $\mathrm{CuO} \mathrm{NP}$ and $\mathrm{Cu}^{++}$ions (as $\mathrm{CuCl}_{2}$ ), when doses are expressed on copper basis. While the reason for the divergent results reported by Karlsson et al. (2008) and us are not obvious, our data suggest that cytotoxicity by $\mathrm{CuO}$ NPs is in fact due to copper release, promoted by the organic components of the growth medium (Gunawan et al. 2011), rather than to a direct interaction between the NP and the biological system. Thus, cytotoxicity by $\mathrm{CuO}$ NPs should be referred, at least under the conditions adopted here, to the paradigm of chemical toxicity. However, nanosize may influence $\mathrm{CuO}$ NP toxicity determining leaching kinetics, as recently proposed by other authors (Gunawan et al. 2011).
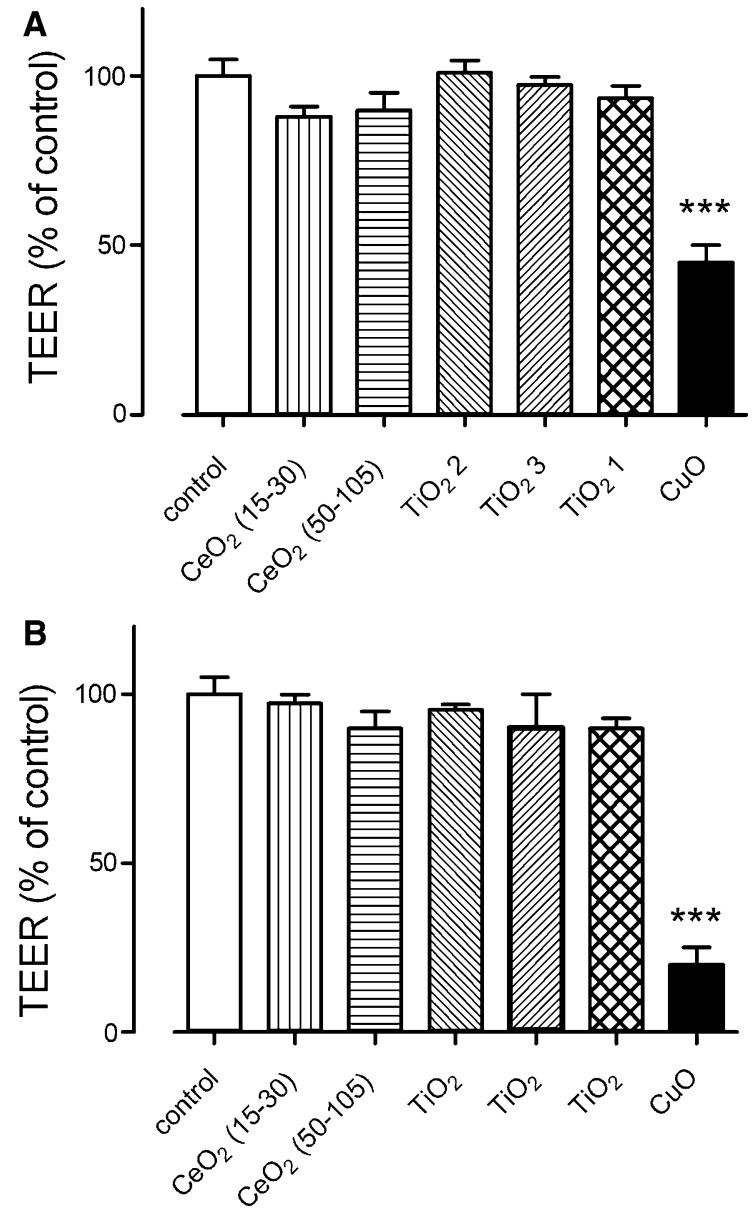

Fig. 10 Effects of metal oxide NPs on the trans-epithelial electrical resistance (TEER) of Calu-3 cell monolayers. Confluent Calu-3 monolayers, grown for 10 days, were incubated in the presence of the indicated NPs at the dose of $120 \mu \mathrm{g} / \mathrm{cm}^{2}$ (for $\mathrm{CuONPs}, 40 \mu \mathrm{g} / \mathrm{cm}^{2}$ ), added at the apical side of the monolayer. The trans-epithelial electrical resistance (TEER) was measured (see 'Materials and methods' section) after two (a) or seven days (b). Data are means of four independent determinations with SD from a representative experiment repeated twice with comparable results. $* * * P<0.01$ versus control, untreated monolayers

In contrast, titanium dioxide NPs have been extensively studied on various cell types and considered relatively poorly toxic (Lanone et al. 2009; George et al. 2011), although some studies report functional alterations, and even clear acute cytotoxicity, in macrophages and airway epithelial cells (Singh et al. 2007; Hussain et al. 2009; Fenoglio et al. 2009; Liu et al. 2011). Moreover, evidence for chronic toxic effects of titania in vivo has been established (IARC 2010; NIOSH 2011). In our experiments, very high 

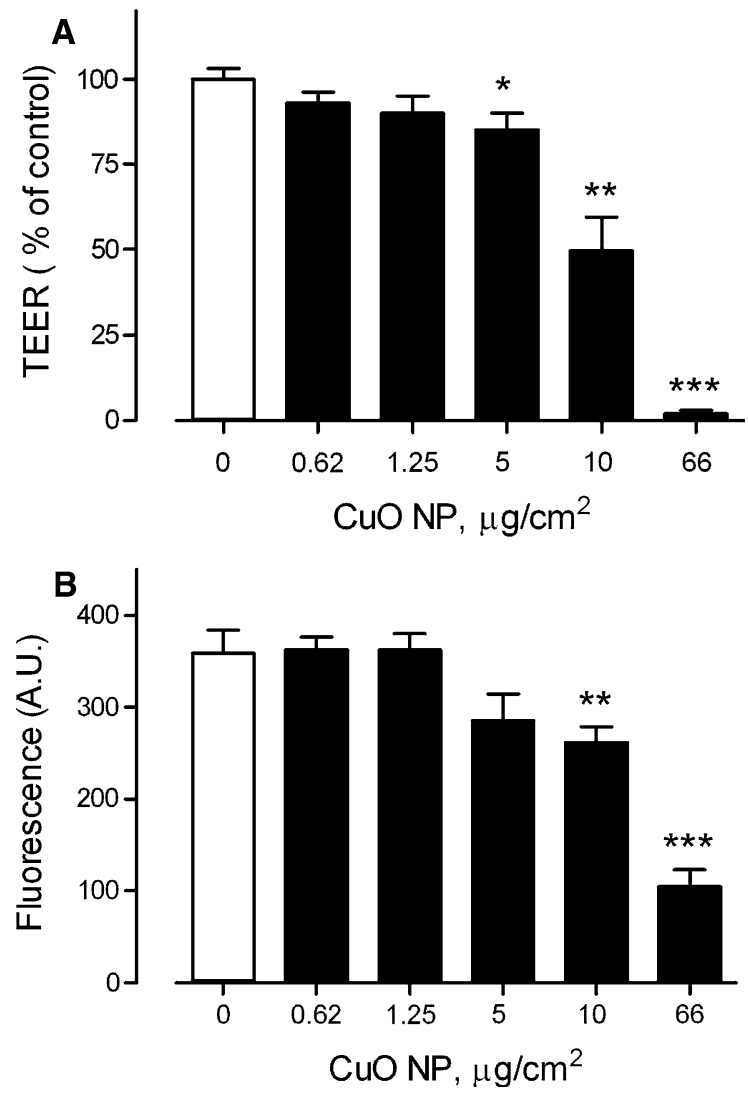

Fig. 11 Dose dependence of the effects of CuO NPs on TEER and viability of Calu-3 cell monolayers. Confluent Calu-3 monolayers, grown for 14 days, were incubated in the presence of the indicated doses of CuO NPs, added at the apical side of the monolayer. After seven days, trans-epithelial electrical resistance (a) and cell viability (b) were determined in the same monolayer. Data are means of three independent determinations with SD from a representative experiment repeated twice with comparable results. *, **, $* * * P<0.05,0.01$ and 0.001 , respectively, versus control, untreated monolayers

doses of titania of different crystalline phase do not cause significant cytotoxicity in either macrophages or airway epithelial cells and do not perturb epithelial permeability. Lack of toxicity cannot be due to limited sensitivity of the methods used, since cytotoxicity was readily detected with either $\mathrm{CuO}$ NPs or Ni NPs, used as a positive control. However, it should be stressed that failure to detect toxic effects may be due to particular conditions of the biological system (such as, for instance, cell type or density of the cell culture during the exposure) and that the absence of overt cytotoxicity does not exclude the possibility of subtler biological effects, such as, for instance, macrophage activation. More importantly, under our experimental conditions, titania are endowed with poor colloidal stability and aggregate in lumps clearly detectable in the micrometric range (Fig. 4), thus preventing the interaction between true nanosized structures and the biological system.

Few toxicological studies on cerium oxide NPs have been published and no information is available on possible correlations between physico-chemical properties and toxic effect for this material. Such studies yielded conflicting results, indicating either cytotoxic (Lin et al. 2006; Xia et al. 2008; Ma et al. 2011) or protective effects (Rzigalinski et al. 2006; Celardo et al. 2011). In our hands, ceria NPs do not appear endowed with significant toxic effects, either on macrophage and airway epithelia viability or on the epithelial barrier. Also for these NPs, however, the same considerations developed above for titania are valid and further studies will be needed to ascertain possible effect on macrophage activation.

The data about effects on TEER of NPs are of particular interest, since they represent the first investigation in which this parameter is evaluated in epithelial cells exposed to metal-based nanomaterials. Interestingly, even at high doses, neither titania nor ceria seem to impair the epithelial barrier, although they have a clear cut tendency to form large aggregates on the monolayers. Conversely, for multi-walled carbon nanotubes, which cause a well-defined barrier impairment in the same biological model (Rotoli et al. 2008), aggregation tendency seems an important factor for the establishment of the toxic effect (Rotoli and Bussolati, unpublished observations). On the contrary, $\mathrm{CuO}$ NP exert a significant toxic effect on the epithelial barrier that closely parallels their effect on cell viability (Fig. 11).

In summary, the strict similarity between the doseeffect relationship of $\mathrm{CuO}$ for toxicity and TEER decrease suggests that TEER provides a simple and sensitive device for the evaluation of NP toxic effects in epithelial models. Moreover, this study confirms the low acute toxicity of titania and ceria and indicates that the high toxicity of CuO NPs may be related to the release of $\mathrm{Cu}^{++}$ions and, hence, modulated by their rate of leaching from the NP.

Acknowledgments Supported by the EU-funded research project 'Safe Nano Worker Exposure Scenarios'-SANOWORK (Grant No. FP7-280716). We thank Mr. Paul Reip (Intrinsiq Materials Ltd., Cody Technology Park, Ively Road, Farnborough-Hampshire, UK) and Prof. Lucia Migliore, University of Pisa, for $\mathrm{CuO}$ NPs. 


\section{References}

Brunauer S, Emmett PH, Teller E (1938) Adsorption of gases in multimolecular layers. J Am Chem Soc 60:309-319

Byrne F, Prina-Mello A, Whelan A, Mohamed BM, Davies A, Gun'ko YK, Coey JMD, Volkov Y (2009) High content analysis of the biocompatibility of nickel nanowires. J Magn Magn Mater 321:1341-1345

Celardo I, De Nicola M, Mandoli C, Pedersen JZ, Traversa E, Ghibelli L (2011) Ce(3)+ ions determine redox-dependent anti-apoptotic effect of cerium oxide nanoparticles. ACS Nano 5:4537-4549

Fenoglio I, Greco G, Livraghi S, Fubini B (2009) Non-UVinduced radical reactions at the surface of $\mathrm{TiO} 2$ nanoparticles that may trigger toxic responses. Chemistry 15:4614-4621

Finkbeiner WE, Carrier SD, Teresi CE (1993) Reverse transcription-polymerase chain reaction (RT-PCR) phenotypic analysis of cell cultures of human tracheal epithelium, tracheobronchial glands, and lung carcinomas. Am J Respir Cell Mol Biol 9:547-556

George S, Pokhrel S, Xia T, Gilbert B, Ji Z, Schowalter M, Rosenauer A, Damoiseaux R, Bradley KA, Madler L, Nel AE (2011) Use of a rapid cytotoxicity screening approach to engineer a safer zinc oxide nanoparticle through iron doping. ACS Nano 4:15-29

German RM, Park SJ (2008) Handbook of mathematical relations in particulate materials processing. Wiley, New York

Gunawan C, Teoh WY, Marquis CP, Amal R (2011) Cytotoxic origin of copper(II) oxide nanoparticles: comparative studies with micron-sized particles, leachate, and metal salts. ACS Nano 5:7214-7225

Hussain S, Boland S, Baeza-Squiban A, Hamel R, Thomassen LC, Martens JA, Billon-Galland MA, Fleury-Feith J, Moisan F, Pairon JC, Marano F (2009) Oxidative stress and proinflammatory effects of carbon black and titanium dioxide nanoparticles: role of particle surface area and internalized amount. Toxicology 260:142-149

IARC (2010) IARC monographs on the evaluation of carcinogenic risks to humans, vol 93. Carbon black, titanium dioxide, and talc. Lyon

Karlsson HL, Cronholm P, Gustafsson J, Moller L (2008) Copper oxide nanoparticles are highly toxic: a comparison between metal oxide nanoparticles and carbon nanotubes. Chem Res Toxicol 21:1726-1732

Kittaka S, Morimoto T (1980) Isoelectric point of metal oxides and binary metal oxides having spinel structure. J Colloid Interface Sci 75:398-403

Kroll A, Dierker C, Rommel C, Hahn D, Wohlleben W, Schulze-Isfort C, Gobbert C, Voetz M, Hardinghaus F, Schnekenburger J (2011) Cytotoxicity screening of 23 engineered nanomaterials using a test matrix of ten cell lines and three different assays. Part Fibre Toxicol 8:9

Lanone S, Rogerieux F, Geys J, Dupont A, Maillot-Marechal E, Boczkowski J, Lacroix G, Hoet P (2009) Comparative toxicity of 24 manufactured nanoparticles in human alveolar epithelial and macrophage cell lines. Part Fibre Toxicol 6:14

Lin W, Huang YW, Zhou XD, Ma Y (2006) Toxicity of cerium oxide nanoparticles in human lung cancer cells. Int $\mathrm{J}$ Toxicol 25:451-457
Liu R, Zhang X, Pu Y, Yin L, Li Y, Liang G, Li X, Zhang J (2011) Small-sized titanium dioxide nanoparticles mediate immune toxicity in rat pulmonary alveolar macrophages in vivo. J Nanosci Nanotechnol 10:5161-5169

Long TC, Saleh N, Tilton RD, Lowry GV, Veronesi B (2006) Titanium dioxide $(\mathrm{P} 25)$ produces reactive oxygen species in immortalized brain microglia (BV2): implications for nanoparticle neurotoxicity. Environ Sci Technol 40:4346-4352

Ma JY, Zhao H, Mercer RR, Barger M, Rao M, Meighan T, Schwegler-Berry D, Castranova V, Ma JK (2011) Cerium oxide nanoparticle-induced pulmonary inflammation and alveolar macrophage functional change in rats. Nanotoxicology 5:312-325

Malugin A, Herd H, Ghandehari H (2011) Differential toxicity of amorphous silica nanoparticles toward phagocytic and epithelial cells. J Nanopart Res. doi:10.1007/s11051-0110524-7

Mao JA, Bai Y, Gu L, van Aken PA, Tu MJ (2010) Preparation and characterization of size-controlled $\mathrm{CeO}(2)$ nanoparticles coated with $\mathrm{SiO}(2)$. J Nanopart Res 12:2045-2049

Nel AE, Madler L, Velegol D, Xia T, Hoek EM, Somasundaran P, Klaessig F, Castranova V, Thompson M (2009) Understanding biophysicochemical interactions at the nano-bio interface. Nat Mater 8:543-557

NIOSH Department of Health and Human Services-Centers for Disease Control and Prevention (2011) Occupational exposure to titanium dioxide. Curr Intell Bull:63

O'Brien RW, Cannon DW, Rowlands WN (1995) Electroacoustic determination of particle-size and zeta-potential. J Colloid Interface Sci 173:406-418

O'Brien J, Wilson I, Orton T, Pognan F (2000) Investigation of the Alamar Blue (resazurin) fluorescent dye for the assessment of mammalian cell cytotoxicity. Eur J Biochem 267:5421-5426

Poland CA, Byrne F, Cho WS, Prina-Mello A, Murphy FA, Davies GL, Coey JM, Gounko Y, Duffin R, Volkov Y, Donaldson K (2011) Length-dependent pathogenic effects of nickel nanowires in the lungs and the peritoneal cavity. Nanotoxicology. doi:10.3109/17435390.2011.626535

Rotoli BM, Bussolati O, Bianchi MG, Barilli A, Balasubramanian C, Bellucci S, Bergamaschi E (2008) Non-functionalized multi-walled carbon nanotubes alter the paracellular permeability of human airway epithelial cells. Toxicol Lett 178:95-102

Rotoli BM, Bussolati O, Barilli A, Zanello PP, Bianchi MG, Magrini A, Pietroiusti A, Bergamaschi A, Bergamaschi E (2009) Airway barrier dysfunction induced by exposure to carbon nanotubes in vitro: which role for fiber length? Hum Exp Toxicol 28:361-368

Rzigalinski BA, Meehan K, Davis RM, Xu Y, Miles WC, Cohen CA (2006) Radical nanomedicine. Nanomedicine (Lond) $1: 399-412$

Salem LB, Bosquillon C, Dailey LA, Delattre L, Martin GP, Evrard B, Forbes B (2009) Sparing methylation of betacyclodextrin mitigates cytotoxicity and permeability induction in respiratory epithelial cell layers in vitro. J Control Release 136:110-116

Sayes CM, Reed KL, Warheit DB (2007) Assessing toxicity of fine and nanoparticles: comparing in vitro measurements to 
in vivo pulmonary toxicity profiles. Toxicol Sci 97:163180

Singh S, Shi T, Duffin R, Albrecht C, van Berlo D, Hohr D, Fubini B, Martra G, Fenoglio I, Borm PJ, Schins RP (2007) Endocytosis, oxidative stress and IL-8 expression in human lung epithelial cells upon treatment with fine and ultrafine $\mathrm{TiO}_{2}$ : role of the specific surface area and of surface methylation of the particles. Toxicol Appl Pharmacol 222:141-151

Soto K, Garza KM, Murr LE (2007) Cytotoxic effects of aggregated nanomaterials. Acta Biomater 3:351-358

Studer AM, Limbach LK, Van Duc L, Krumeich F, Athanassiou EK, Gerber LC, Moch H, Stark WJ (2010) Nanoparticle cytotoxicity depends on intracellular solubility: comparison of stabilized copper metal and degradable copper oxide nanoparticles. Toxicol Lett 197:169-174

Suttiponparnit K, Jiang J, Sahul M, Suvachittanont S, Charinpanitkul T, Biswa P (2011) Role of surface area, primary particle size, and crystal phase on titanium dioxide nanoparticle dispersion properties. Nanoscale Res Lett 6:441. doi:410.1007/s11671-11010-19772-11671

Xia T, Kovochich M, Liong M, Madler L, Gilbert B, Shi H, Yeh JI, Zink JI, Nel AE (2008) Comparison of the mechanism of toxicity of zinc oxide and cerium oxide nanoparticles based on dissolution and oxidative stress properties. ACS Nano 2:2121-2134 